\title{
Proverbs 23:29-35 in the light of the role of the church in Nigeria in curbing alcoholism
}

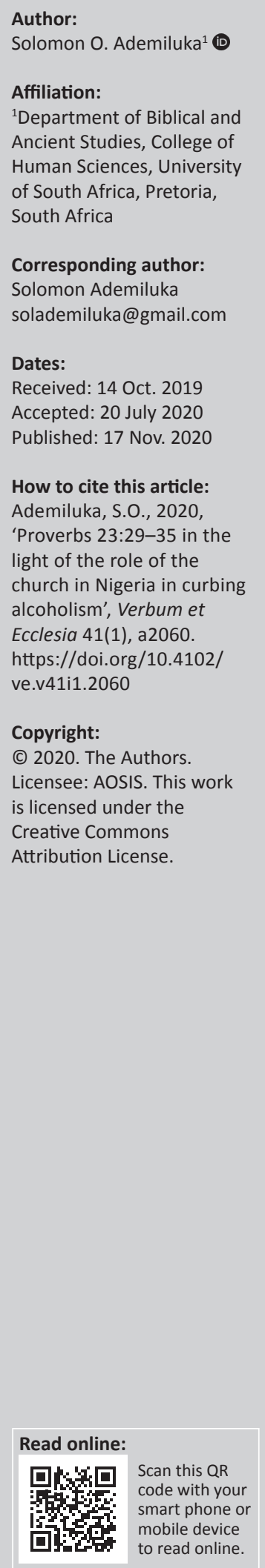

The effects of alcohol indicated in Proverbs 23:29-35 are very much applicable in the modern world, particularly in Nigeria where the substance is massively abused. As a result, numerous men are suffering from alcohol-related diseases whilst many have died on account of such ailments. Much of the violence in the homes and the society at large is aided by alcohol. The aim of the article is to examine the relevance of Proverbs 23:29-35 in contemporary Nigeria and how the church can help in curbing alcoholism and its concomitant effects. The target group is the teeming population of old and young Nigerian men amongst whom alcoholics are mostly found. To achieve this aim, the exegetical and descriptive approaches were employed. It was found that the text creates awareness for the church concerning the prevalence of alcoholism with its adverse effects in the society. The essay concluded that the church could respond to the problem of alcoholism by constituting an alcohol recovery programme with the Proverbs 23:29-35 passage as part of the teaching and counselling instruments. This programme would involve the church encouraging its members to have a compassionate attitude towards alcoholics and engaging professional counsellors in helping them to regain sobriety. The church could also establish Alcoholics Anonymous groups, which would help the alcoholics themselves to participate in their own process of healing. In this way, the church would be helping immensely in curbing the effects of alcoholism in Nigeria.

Intradisciplinary and/or interdisciplinary implications: This research involves the disciplines of the Old Testament and Christian Ethics. It examines the relevance of Proverbs 23:29-35 in Nigeria, and the role of the church in curbing alcoholism. The author believes that the church can play a significant role in getting healing for alcoholics, thereby reducing the effects of alcoholism in Nigeria.

Keywords: the book of proverbs; alcoholism; alcohol abusers; the church; Nigeria.

\section{Introduction}

Proverbs 23:29-35 reflect effects of alcohol on drinkers that are reminiscent of common experience in the modern world. In Nigeria, alcohol consumption is a conspicuous feature of daily life. In almost all the major towns, from about 16:00 till about midnight every day, alcohol drinking is a major activity in shops and in the open along the streets. For all ceremonies, alcohol is the main attraction for both young and old men. In Nigeria, alcohol is not only massively consumed but also massively abused. Addicts are not at all lacking everywhere; very often one comes across some fellows who appear near lunatics on account of addiction to liquor. There is a lot of disturbance of peace because of uncontrolled alcohol consumption. Many marriages have collapsed because of alcohol abuse on the part of men. Many men are suffering from alcohol-related diseases whilst numerous have died of such ailments. Unfortunately, in spite of its adverse effects on alcoholics and the society at large, abuse of alcohol is still one of those social vices that are yet to adequately engage the attention of government in Nigeria.

The aim of the article is to examine the relevance of Proverbs 23:29-35 in the Nigerian context and the role the church can play in curbing alcohol abuse. The target group is the teeming population of old and young men amongst whom the addicts are usually found. The work employs the exegetical approach for the study of the text, the descriptive method for the analysis of the abuse of alcohol in Nigeria and the role of the church in combating the menace. It begins by examining the wine culture in the Hebrew Bible or Old Testament (HB or OT), after which it does an exegesis of the text. The essay proceeds to do an analysis of alcohol abuse in Nigeria and its effects on the society and finally the role of the church in curbing alcoholism. 


\section{The wine culture in the Hebrew Bible/Old Testament}

The burden of Proverbs 23:29-35 is the wrong use of substances commonly translated in the English versions as 'wine'. However, an examination of the relevant texts reveals that the word 'wine' 'is used to translate some dozen Hebrew and Aramaic words of varying significance' (Kerr 1968:11). Amongst those words, ין (yayin) is the most frequently used. According to Boone (n.d.), יין may refer to fermented, intoxicating wine or unfermented grape juice (p.4). In its first occurrence in Genesis 9:20 and 21, י 'describes the intoxicating effects of fermented wine' (Bacchiocchi 2001:52). Amongst other examples where it also refers to alcohol is the narrative of Lot's daughters seducing him with wine in order to make him have sex with them (Bacchiocchi 2001:52; Boone n.d.:4; cf. Gn 19:32-33). In 2nd Samuel 13:28, Amnon was murdered by the servants of his brother Absalom whilst the former was drunk with יין. Other cases in which " means alcohol are those texts that reflect the 'classic condemnation of the use of intoxicating wine and a description of its consequences [as] found in Proverbs 23:29-35 [cf. 20:1]' (Bacchiocchi 2001:53). According to Bacchiocchi (2001), the use of "י to denote unfermented grape juice is not as explicit as in those texts in which it refers to alcohol. 'There is no single passage which clearly defines yayin as unfermented grape juices [but] there are [those] where the context clearly indicates that the word designates unfermented grape juice' (Bacchiocchi 2001:53). One example is in Isaiah 16:10 where '... no treader [would] tread out wine [yayin] in the presses ...' which is a clear reference to unfermented grape juice before the process of fermentation (Bacchiocchi 2001:54). Another case in which refers to unfermented grape juice is in Jeremiah 40:12: 'They gathered wine [יין] and summer fruits in great abundance' (cf. Neh 13:15). Here "' must 'refer to the fruit of the vine [because] [a] lcoholic wine is not gathered from the fields' (Bacchiocchi 2001:55).

Whilst " may refer to alcoholic and non-alcoholic wine, as Boone (n.d.) rightly notes תירוש (tirosh) is the most common Hebrew word for unfermented wine, as '[i]t is often translated "new wine"' (p. 6). According to Kerr (1968), the term is variously translated in the Authorized Version (AV) as 'wine', 'new wine', and 'vintage' but always as 'new wine' in the revised versions. He explains that תירוש 'indicates the freshly pressed juice of the grape [and] ... frequently named as a product of the soil and grouped with oil and olives and cereals' (p. 12; cf. Nm 18:12; Jl 2:19). However, in view of Hosea 4:11 where "תירוש are said to 'take away the understanding' Revised Standard Version (RSV), some have argued that 'tirosh refers to an intoxicating drink' (Boone n.d.:4). But from Isaiah 65:8 the term seems to refer originally to unfermented juice as it talks about תירוש that is found in the cluster, and 'grapes do not ferment on the vine' (Boone n.d.:6). This fact may be buttressed with the fact that except in Hosea 4:11, the term 'is always described as a blessing from God' (Kerr 1968:12).
Shekar (שכר) is another Hebrew word also translated as 'wine'. It is usually translated as 'strong wine' or 'strong drink'. The word is said to have come from a root meaning 'to be drunk', hence 'it clearly refers to an intoxicating beverage' (Boone n.d.:6). Kerr (1968) noted that the words ישכר and, often translated as 'wine and strong drink' 'occur together a number of times always indicating intoxicating beverages' (p. 11). However, שכר must have differed from יין in the sense that the former was made, not from grapes, but fermented juice of the date, barley, honey 'or other fruits that could be used for strong drink' (p. 11). Later שכר came to designate 'every sort of intoxicating beverage from whatever source derived' (p. 11).

Another word translated as wine is חמר (chemer). According to Kerr (1968), the term

$[D]$ enotes a thick, sticky syrup or foaming juice ... [and] may indicate all types of wine [hence] in Deuteronomy 32:14 the term is described [as] the pure blood of the grape. (p. 12)

Boone (n.d.) states that 'the word might refer either to the colour of the grapes that would be pressed or to fermented wine' (p. 4). Its Aramaic form, (chamar), is used only in Ezra 6:9, 7:2 and Daniel 5:1-4 where its 'use corresponds to yayin, that is, it may be used of every type of wine' (Kerr 1968:12; cf. Boone n.d.:4). Another word is ממסך (mimsak) that usually connotes 'mixed wine' (Carr 1980:516). The term derived from 'the idea of something that is mixed [which] could be referring to diluting with water or mixing with other juices or spices' (Boone n.d.:5). As Kerr (1968) put it, 'mimsak was applicable to many mixtures of wine with water or with aromatics' (p. 12). ממסך is used only two times, in Proverbs 23:30 where it is translated as 'mixed wine' and in Isaiah 65:11 where it is 'drink offering' Whereas its nature in Isaiah is not clear, the context in proverbs suggests that the term refers to an alcoholic drink as it warns against drunkenness (Boone n.d.:5).

Sobe' (סבא) appears to be another type of drink that could be mixed with other substances like water for drinking as wine. This is the sense in which it is used in Isaiah 1:22, where it is mixed with water. Kerr (1968) therefore opined that sobe' 'probably indicates boiled grape-juice and therefore a thick, non-alcoholic liquid to be mixed with water' (p. 12). 'Asis (עסיס) occurs in Isaiah 49:26, Joel 1:5 and Amos 9:13, and in each case rendered as 'new wine' or 'sweet wine'. Kerr (1968) opined that the term refers to 'the fresh juice of the grape' (p. 12). Similarly, Boone (n.d.) asserts that the word "comes from a root meaning "to press out" [hence] [i]t refers to freshly pressed out juice' (p. 5). 'Enab (עבב) is almost always translated as 'grapes' except in Hosea 3:1 where it reads 'wine' in the King James Version (KJV) (Boone n.d.:5). Yeqeb (יקב) normally refers to the winepress, 'the instrument used to make the wine' (Boone n.d.:4); Kerr says it denotes 'a cavity or vat in which the grapes or olives were put for the purpose of being trodden' (p. 12). However, in Deuteronomy 16:13 the KJV translates it as 'wine'. 
It can be deduced from the above discussion that production of wines was an important aspect of the Hebrew agricultural economy. Hence, Kerr (1968) noted that the 'frequency with which wine, the vine and vineyards are mentioned shows that it was recognized as a subject of considerable importance in the pre-Christian era in Palestine' (p. 11). In this regard, Patton (n.d.) stated that the numerous texts related to wine and wine production 'settle the fact that Palestine abounded in sweet fruits - that the Hebrews cultivated the grape and made wine' (p. 17). In Israelite life, wine had both a secular and religious use. Wine is an important item in the 'elaborate catalogues of dietary provisions' (Charles 1966:5; cf. $1 \mathrm{Sm}$ 25:18; $2 \mathrm{Sm}$ 16:1-2). Sometimes it seems bread and wine constituted the entire Hebrew meal (Jdg 19:19; Rt 2:4), whilst at 'other instances wine along with bread and meat appear to represent the basic elements of nourishment' (Charles 1966:5; cf. 1 Sm 10:3; 16:20). Whereas the use of wine amongst the poor must have been 'limited by economic necessity [i]n more affluent and aristocratic circles it was drunk in large quantities' (Charles 1966:5; cf. Am 6:4-6). The wine also played a significant role in the sacrificial system wherein they served as drink offerings. It is important to note that apart from Numbers 28:7 where strong drink (שכר) is used for a libation, the drink offering is usually wine (יין). But it must be further noted, as Kerr has reiterated that in the sacrificial system of Israel there is no evidence that the drink offering was drunk' (p. 12). Although there are no known instructions concerning how the wine was to be offered, 'from later evidence it appears that, like the blood, it was poured out at the foot of the altar' (p. 12; cf. Charles 1966:5).

In the HB or OT the basic attitude towards wine was essentially positive. It was reckoned as God's gifts to his people to gladden their hearts (Ps 104:15). However, the potential evils of the misuse of wine are clearly shown. Drunkenness and its attendant problems are graphically described. For instance, Amos denounces the women of Samaria who compelled 'their husbands to oppress the poor in order to secure money to buy wine' (Charles 1966:6; cf. Am 4:1). As mentioned earlier, Hosea warns that wine takes away the understanding (4:11). Isaiah (5:11; cf. v. 22) condemns those who rise early in the morning seeking strong drink and those who tarry late in the evening till they get drunk. The prophet also speaks against religious leaders, priests and prophets who 'reel with strong wine and are confused with wine' (Is 28:7). Apart from Proverbs 23:29-35, some other portions in proverbs point to the dangers of wine and repeatedly warn against its misuse. It must be emphasised, however, that 'these and similar warnings are directed against the evils of excessive drinking' (Charles 1966:7). Although it was forbidden for some like the priests (whilst on sacred duty, Lv 10:9, 10; cf. Ezk 44:21; cf. Kerr 1968:11), the Nazirites (Nm 6) and the Rechabites (Jr 35), '[n]owhere in the OT is the principle of total abstinence laid down as a rule applicable to all' (Charles 1966:7). Thus, the HB or OT has indicated the availability, consumption and sometimes abuse of alcohol, thereby providing a background for the proper understanding of
Proverbs 23:29-35. The following section offers an exegesis of this text.

\section{An exegesis of Proverbs 23:29-35}

Proverbs 23:29-35 conform intrinsically to the theme of character which is the central subject of the book. Proverbs identify the two forms of conduct, namely those of righteous living and wicked living. 'The path of righteousness or wisdom is the path of virtue, whereas the path of wickedness or folly is the path of vice' (Zuck 1991:241). Righteousness brings blessing, whereas wickedness brings bane (2:13-15; 4:19). The book brings out certain virtues that indicate the path of wisdom or righteousness and vices that show the way of the wicked or foolish. Righteousness is depicted in virtues such as patience and self-control (14:29; 17:27; $19: 11 ; 29: 11)$, courage $(28: 1)$, love $(10: 12 ; 16: 6 ; 20: 28)$, reliability (11:13; 25:13), truthfulness (12:17, 19, 22; 14:5, 25; 16:13), kindness (11:17), and so forth. Along with vices like greed $(15: 27 ; 28: 25 ; 29: 4)$, envy and jealously $(3: 31 ; 6: 34 ; 14: 30 ; 23: 17$; $24: 1,19 ; 27: 4)$, drunkenness, which is the burden of Proverbs 23:29-35 (cf. 20:1; 21:17; 23:20-21; 31:4-7), indicate the path of foolishness (Zuck 1991:241). Proverbs 23:29-35 belong to the literary unit in 22:17-24:22, which is the third of the eight main sections of the book. Incidentally, this literary unit has been found to exhibit striking similarities with an Egyptian document discovered in 1926, the so-called Instructions of Amen-em-opet, which dates to 8th-7th century BCE (Birch et al. 2005:392; Rylaarsdam 1982:386; Boadt 1984:447). According to Goldingay (1994), Proverbs 22:17-24:22, like the teaching of Amen-em-opet, are 'designed to offer advice to people involved in public service' (p. 602). Amongst other things, they are to heed the insights of wisdom (22:17-21) and to beware of the danger of self-indulgence (23:1-9). Proverbs 23:29-35 warn them of the problem of selfindulgence as it relates to abuse of alcohol.

In Proverbs 23:29-35, the target of the author is the drunkard (v. 30). In verse 31 , the sage describes the enticing properties of alcohol, whereas in 29, 32-35 its effects on the drunkard are laid out. Ulrich (2018) recognised the distinctive characteristics of this passage in 'its long length and extensive use of satire to portray a drunken man' (p. 114). Garrett (1993) opined that the unit 'describes with profound accuracy ... the pathetic physical and emotional decline of those addicted to alcohol' (p. 197). The six rhetorical questions asked in verse 29 find answer in verse 30 in 'They that tarry long at the wine; they that go to seek mixed wine' (KJV). The reference, then, clearly is to drunkards. The sage might be thinking of addicts who are not satisfied with drinks of low alcoholic content and have to go looking for stronger ones. What they are habitually searching for is ממסך which may connote 'drink-offering' or 'mixed wine', as earlier noted, but the context here makes it clear that the drink refers to strong alcohol, 'some very strong and more heady and intoxicating' drink (Bible Study Tools 2020). Verse 31 depicts the characteristic red colour of as it bubbles in the wine bag (כיס). Henry (2012) stated that the red wine (יי) was called the blood of the grape and 'was looked upon as the best wine' (online). The verb הלך is used 
here in Hithpael (to walk to and fro) apparently to describe the sparkles of wine as they move up and down inside the glass. It may also describe wine as it 'goes down the throat pleasantly; or rather looks well to the eye, and appears right and good, and promises a great deal of satisfaction and delight' (Bible Study Tools 2020). But the sage admonishes his audience not to look at these enticing characteristics because of the harm they would do when they enter the belly of the consumer (cf. Pr 20:1). The wine 'should not be looked upon with a greedy eye, so as vehemently to desire it, which will lead to an intemperate use of it' (Bible Study Tools 2020). Commenting on this verse, Ulrich (2018) says,

[I] $\mathrm{t}$ may be that the sage recognizes that [the] temptation [to getting drunk] begins with a glance and hence the most effective means of dealing with [the] temptation is not to allow it to happen. The wisdom here, then, recognizes the folly of drunkenness and the value of not only keeping oneself from foolish behavior, but from situations which create the temptation to behave foolishly. (p. 114)

In verse 32 , the author discloses the effects of alcohol when it gets inside the drinker: 'it bites (נשך) like a serpent and stings (פרש) like an adder' (RSV). The intent of the author in this expression seems to be clearer in the Septuagint (LXX): 'But at the last he stretches himself like one stricken by a serpent, and the venom is diffused through him as by a horned snake' (Studylight.org 2020:online). Similarly, the Latin Vulgate says, 'It will diffuse its poison like a basilisk' (Studylight.org 2020:online). Thus, 'though it goes down sweetly, yet [strong wine] leaves a sting behind it' (Bible Study Tools 2020:online). It 'is like the subtle poison of a serpent, which affects the whole body and produces the most fatal consequences' (Studylight.org 2020:online).

In verses 29, 33-35 the emotional, social and physical effects of intoxication on the drunkard are described. As Ulrich (2018) rightly observed, the poetic questions in verse 29 'draw attention to three kinds of trouble caused by intoxication [namely] emotional (“'Who has woe? Who has sorrow"), social ("Who has strife? Who has complaining?") and physical ("Who has wounds without cause? Who has redness of eyes?")' (p. 114). The word (woe) is said to be 'an onomatopoetic interjection, which creates an expression of grief and despair [always having] a negative impression' (Njoku 2012:44). The sage, here then might have in mind the grief that is associated with drunkenness. אבוי is another interjection, often rendered as 'sorrow' by most English versions. Another author links the term with sorrow that one incurs from tarrying in drinking places (Njoku 2012:44). Commenting on the word מדונים (strife) in this verse, Henry (2012) stated that intoxication 'embroils men in quarrels, makes them quarrel with others, and say and do that which gives others occasion to quarrel with them' (online). שיח is commonly translated as 'complaining'. However, it is reasonable to suppose that the sage has the characteristic mutterings of a drunkard in mind, in which case the KJV translation of 'babbling' might be more appropriate. Drunkards also do have wounds (פצעים) 'which might have been avoided [in that such might be] the result of quarrels in which a sober man would never have engaged' (Studylight. org 2020:online). They may also incur wounds 'without cause because they are not in capacity to judge the right or wrong causes' (Henry 2012:online). The Hebrew חכלילות is rendered as 'redness of eyes' by most English versions but many modern commentators are of the view that the word "indicates "dimness of sight," that change in the power of vision when the stimulant reaches the brain' (Studylight. org 2020). For the modern reader, Ross' (1994) paraphrase of verse 29 is most appropriate:

$[T]$ he ... one who drinks too much ... raves on and on, picks quarrels, and fights, ... is unable to speak clearly, poisons his system with alcohol, gets bloodshot eyes. (p. 990)

In verse 33, as the drunkard gets his system poisoned, so his eyes are seeing 'strange things' (זרות) and his mind uttering 'perverse things' (תה (תפכות). In modern times, the author would have said the drunk would be seeing 'hallucinations', as in the New Living Translation (NLT). The KJV translates זרות as 'strange women' but there is certainly no basis for it in the Hebrew. Hence, the Targum and many commentators render it as 'strange things' (Bible Study Tools 2020). In that case, by this term 'the writer intends to denote the fantastic, often dreadful, images produced on the brain by the feverish condition of the inebriated' (Studylight.org 2020:online). As another commentator puts it,

$[T]$ hrough the lunges and vapours that ascend into his brain, [a drunken man] fancies he sees strange sights; he sees things double; imagines that he sees trees walk, and many such like absurd and monstrous things (Bible Study Tools 2020:online).

Commenting on the term תוכפההת , Henry (2012) stated that when men are drunk

[T] he tongue grows unruly and talks extravagantly [and] by it the heart utters perverse things, things contrary to reason, religion, and common civility, which they would be ashamed to speak if they were sober. (online)

When the drunken man lies down, he feels as if he is in the heart of the sea or on top of a mast (v. 34). In these expressions the drunk is likened 'to one who is drowned or drowning ... and has become unconscious of surrounding circumstances' (Studylight.org 2020:online). They may also be a pointer to the dangers that a drunkard is exposed to; being in a 'great danger as one in the circumstances described, in a storm at sea' (Bible Study Tools 2020:online). This verse thus describes the drowsiness suffered by alcoholics (cf. Pr 23:21). In the words of Henry (2012):

$[T]$ heir heads are giddy, and when they lie down to sleep they are as if they were tossed by the rolling waves of the sea, or upon the top of a mast. (online)

Verse 35 portrays the numbness of the drunken man's body as an effect of alcohol. His condition has rendered him so insensible to pain that 'though he has some vague idea that he has suffered certain rough treatment ... it has made no impression on him' (Studylight.org 2020:online). In this 
regard, Henry (2012) opined that when men are drunk ' $t$ they are heedless and fearless of danger. Drunkenness turns men into stocks and stones' (online). As he does not recognise his degradation, the alcoholic is still 'looking forward with pleasure to a renewal of his debauch, when his drunken sleep shall be over' (Studylight.org 2020:online). This last part of the verse reads in the Latin Vulgate, 'When shall I awake, and again find wines?' (Bible Study Tools 2020: online). Thus, even when he is 'heavy with sleep through intemperance, and yet thirsty, [the drunkard] is desirous of shaking off his sleep [and] get [ting] to drinking again' (Bible Study Tools 2020:online). As Henry (2012) put it, apparently because the drunkard is not alive to the effects of alcohol on him, and because of the pathological thirst created by his addiction, once his eyes are clear he begins to look for drinks again.

[I]t is as though the drunkard has to yield to the effects of his excess and sleep off his intoxication, but he is, as it were, all the time longing to be able to rouse himself and recommence his orgies. (Studylight.org 2020:online)

Dependence on alcohol depicted here may be understood in the words of the ex-alcoholic pastor, Alexander DeJong, when he writes, 'While I was still drinking ... much as the passage [Pr 23:29-35] gnawed at me, I could not stay away from it' (DeJong 1985:54).

This exegesis is perhaps best summarised for the modern reader in Collins' (2007) paraphrase of the text thus:

Who has anguish? Who has sorrow? Who is always fighting? Who is always complaining? Who has unnecessary bruises? Who has bloodshot eyes? It is the one who spends long hours in taverns, trying out new drinks. Don't let the sparkle and smooth taste of wine deceive you. For in the end it bites like a poisonous serpent; it stings like a viper. You will see hallucinations, and you will say crazy things. You will stagger like a sailor at sea, clinging to a swaying mast. And you will say, 'They hit me, but I didn't feel it. I didn't even know when they beat me up. When will I wake up so I can have another drink?' (p. 660)

In Proverbs 23:29-35, then, the author advises men against alcohol abuse because of its inherent dangers to the abuser, dangers from which other members of the society may not be absolved. In the following section, this article relates the discourse to the effects of alcohol abuse in Nigeria.

\section{Relating Proverbs 23:29-35 to alcoholism and its effects in Nigeria}

Just like the ancient Hebrews had various types of wine, from time immemorial Africans have been producing alcoholic beverages from a wide variety of 'fruits, grains and other natural substances' (Nugent 2017). African traditional drinks include:

$[T]$ he thick, cloudy grain beers of the savannah areas of East and Southern Africa and the Sahelian zone, and the palm and banana wines of the higher rainfall areas, especially in
Central and West Africa as well as coastal areas. (Bryceson 2002:online)

In the pre-colonial era, these alcoholic drinks were produced locally, palm wine being tapped from the raffia and oil palm, the grain beer fermented from cereals such as maize and sorghum. As a form of development over the traditional methods, local gin has been distilled from palm-wine in many African communities (Odejide 2006:28). In the Nigerian context, Obot (2007:519) has identified three major categories of traditional alcoholic drinks, namely fermented products such as burukutu from maize and pito from millet and guinea corn, palm wine from the palms and the gin-like distillates of these drinks. The latter is known in most parts of West Africa as ogogoro, kinkana, kaikai or apeteshi. Whereas distilled drinks are sold beyond their places of production, the others are mostly consumed where they are produced. Thus, fermented beverages are well known in the savannah region of central Nigeria, whereas palm wine is popular in the southern parts of the country where raffia and oil palms abound. Distilled from maize or sorghum, pito is the traditional drink of the Binis in the mid-western part of Nigeria but now very popular in most parts of the country because of its low price. The tapped wine, cereal beverages and their distillates were the traditional drinks of the Nigerian people until 'the western traders brought industrialised spirits in the latter part of 19th century' (Odejide 2006:28).

In the pre-colonial era, alcohol was part of everyday life, particularly in such communities where its production was closely intertwined with its consumption as staple food. In many places alcohol still serves as a medium for communication with the ancestors, and thus 'has always had a central place in African religious belief. [In addition,] in urban and rural areas alike, drinking provides a focal point for relaxation and socialising' (Bryceson 2002). Today, alcohol still plays a major role 'in religious rituals, marriage ceremonies, kingship enthronements, cultural festivals, child naming', and so forth (Dumbili 2013:21; cf. Obot 2007:519). It is noteworthy, that the social and religious usages of alcohol in Africa are reminiscent of those of the ancient Hebrews discussed earlier.

In the traditional African setting, alcohol consumption was controlled so much so that excessiveness was far rarer than it is today. 'Although alcoholic drinks have often been made by women, it is senior men who typically defined who could drink, how much and in what contexts' (Nugent 2017:online). Even today, in most communities ' $s$ ] nctions against women drinking too much or specific types of alcohol are widespread' (Bryceson 2002:online). In the traditional Nigerian society, for instance amongst the Yoruba of the south west,

$[T]$ he use of alcohol was restricted to adult males and it was essentially for pleasure at the end of the day's farming activities. [There existed] ... unwritten prohibition of alcohol use by females and children'. (Odejide 2006:28) 
Dumbili (2013) stated that in the traditional Nigerian setting, alcohol

$[W]$ as mainly consumed by adult males in social engagements and customs, [and wherever] young people ... were permitted to drink, this was usually in the presence of adults who monitored the quantity they consumed. (p. 22)

However, the pattern of alcohol consumption in Nigeria and Africa at large has changed considerably, particularly because of western influence. This change began with the commercial tie between Europe and Africa, the trade in which alcohol 'was an article of the barter system through which European goods were exchanged for African slaves' (Odejide 2006:28; cf. Bryceson 2002). Before the coming of the Europeans, Dumbili (2013) explained:

Where trade in alcohol did exist, it was on a remarkably low scale [but] [ $t$ ]his trend was altered in Western Africa following the influx of European slave traders and their 'trade spirit'.[T] he influence of the Western traders popularised the sale of liquor and facilitated alcohol abuse due to the importation, sale and distribution of trade spirit. This trend was sustained during the colonial era and beyond, leading to the establishment of the first brewery [in Nigeria] presently known as Nigerian Breweries in 1946. (p. 22)

Nigerian Breweries started industrial production of western beer in 1949 followed by the Guinness brewery in 1962 (Obot 2007:519). By 1984, each of the 19 states then had its own breweries (Dumbili 2013:23). The result of this development is that:

[T]he use of traditional alcohol beverages such as palm-wine, palm-wine distillate, or alcohol from cereals appears to be declining [while] industrialized beer has become the most popular with adolescents and young persons. (Odejide 2006:28)

The pattern of change involves not only the brand of drinks but also the manner of consumption. Drinking is no longer regulated by custom and tradition, neither is it reserved for social gathering and entertainment (Dumbili 2013:22). A study by Gureje et al. (2007) revealed that 'heavy episodic drinking, rather than moderate drinking is common amongst users of alcohol in Nigeria' (cited in Dumbili 2013:23). Other studies have shown the increasing consumption of alcohol by women and the negative consequences associated with it (Dumbili 2013:23). A new development that has aided the increase in the consumption of alcohol amongst youngsters is 'the alcohol contest in bars, restaurants, drinking joints, hotels and nightclubs ... in which a large sum of money ... is awarded to the fastest drinker' (Dumbili 2013:22). Such contests are usually conducted by marketers to introduce new products or to promote existing ones.

Thus, alcohol consumption in Nigeria has been on a sharp increase. Moreover, Obot (2007:520) noted that several surveys show that more than half of drinkers report drinking to intoxication. It is therefore no surprise that Nigeria is currently amongst the heaviest consumer countries of alcohol in the world. According to Dumbili (2013), a 2004 report by the World Health Organisation (WHO) ranked the country 'amongst 30 countries with highest per capita consumption of alcohol globally' (2004:23). Chukwuonye et al. (2013:180) asserted that data from WHO 'released in 2011 [reveal] that Nigeria tops the list of African countries in alcohol consumption'. In 2012, Nigeria was the world's second biggest consumer of Guinness, after Britain, and it was then reported that beer 'turnover in Nigeria [was] growing faster than its economy' (Alcohol sales surge in Nigeria 2012). In 2017 Nigeria was rated the number one in Africa for alcohol consumption' (Helicopter View 2017). ${ }^{1}$

Alcohol abuse in Nigeria is already indicated here in the tendency to drink to the point of intoxication and in the socalled contests. Massive abuse is witnessed by other means, particularly aided by the marketing activities of the various companies, targeting young men and women, especially students. Dumbili and Williams (2016) rightly observed that the marketing activities of the alcohol producing companies have gone a long way in contributing to 'the easy accessibility and misuse of alcohol amongst Nigerian youths' (p. 138). In this light, a worrisome recent development is the increasing rate of 'drinking amongst youths as a means of showing off in public places' (Dumbili 2013:22). This is worsened by the fact that the law on drinking age is never enforced. 'Although the minimum drinking age remains 18 years, young people buy and drink alcohol freely in public places' (Dumbili 2013:22). Moreover, youngsters apparently take pride in being able to drink beer in large quantity. In the study conducted by Dumbili and Williams (2016), it was discovered that:

$[Y]$ oung people use the consumption of large quantities of alcohol to construct a range of gender identities in leisure spaces. The data revealed that what mattered most among men is the 'number of bottles' of ... beer one consumes and not necessarily its potency. In this light, men strived to outdrink their peers in each drinking episode, to the extent that one of them had to change his brand from stout [to a less potent brand] just to remain competitive. (p. 142)

Episodic drinking of the type mentioned above usually takes place during 'ceremonies ... [when young men boast] of drinking six to eight bottles of beer in a single episode' (Nelson 2015:108). But heavy drinking of similar nature also occurs on daily basis by some men who have formed the habit of getting drunk every evening. Alcohol abuse in this way is aided by 'outdoor-open space drinking that [has long become] the common drinking trend in Nigeria' (Lasebikan et al. 2018:6). According to Lasebikan et al. (2018),

[T] here has been a rapid shift in the social context of drinking with a large proportion of regular drinkers favouring outdooropen space drinking. Suchopen-place drinking is at motor-parks, by the road sides, the majority of which are unlicensed premises for drinking. To entice consumers, alcohol vendors provide [side attractions] such as big television [sets] for their customers to watch soccer and movies as well as music. (p. 1)

A few features of the outdoor drinking places are uncontrolled consumption and the regular presence of hardened addicts to whom such places have become second homes. Another

1.It must be mentioned that heavy consumption of alcohol and its abuse is witnessed more in the southern and central regions of the country as against the north where more in the southern and central regions of the country as against
there is some form of restraint because of the prevalence of Islam. 
development that is worthy of emphasis is the increasing rate of alcohol consumption by women. Dumbili (2013) attributed this trend to:

[T] he rising influence of globalisation and the upsurge of feminism ... [by virtue of which] women have recently begun to challenge the status quo that relegated them to the background [which] seems to have been extended to alcohol consumption'. (p. 23)

Having acquired education and other empowering skills to enrich themselves, many women have thrown off the traditional restriction on women and are now competing with men in heavy alcohol consumption (Dumbili 2013:23). It is common knowledge that, although far less in number than men, women are usually present in the outdoor drinking places mentioned here, and it is needless to say that there are many female alcoholics today in Nigeria.

Abuse of alcohol also occurs in Nigeria in a way similar to the use of the term ממסך in Proverbs 23:29, as examined in the previous section. It is the mixing of alcohol with substances, particularly herbs to produce alcoholic herbal mixtures. Such preparations are produced by mixing hot drinks, particularly ogogoro, 'with herbs or root of trees and administered as medications' (Dumbili 2013:24). This practice is very common but it is most noticeable in motor parks where such products are sold by vendors to drivers of commercial vehicles (Dumbili 2013:24). Alcoholic herbal mixtures are very popular in the major motor parks in Yorubaland in the south west. For instance, at most of the parks in Ibadan various types of alcoholic herbal mixtures are hawked by vendors and sold to drivers, as such preparations are believed to cater for the stressors of driving (Lasebikan \& Ayinde 2012:368). In addition, the mixtures 'are believed to have various medicinal values ... [for] treating haemorrhoids [while some are] ... believed to be aphrodisiacs [or] to improve semen quality' (Lasebikan \& Ayinde 2012:369). A similar practice exists in the riverine areas where hot drinks are consumed heavily with the claim that it keeps the body warm. For instance, the inhabitants of Oron, Akwa Ibom State believe that as fishermen who live near the river they have to 'take a lot of hot drinks to keep themselves warm' (Nelson 2015:108).

In terms of effects, Proverbs 23:29-35 are most relevant in modern times in the context of the concept of alcoholism. Various terms have been used to refer to problems with alcohol, such as 'problem drinking', 'alcoholism', 'chemical dependency', 'alcohol abuse', etc.; all of which 'broadly refer to situations in which drinking causes continued uncontrolled problems or harmful consequences in any area of life' (Haarer 1984:44). According to Collins (2007):

$[D]$ ependence on alcohol is what normally is called alcoholism, [the] [c]ommon symptoms [of which] include a strong need or compulsion to drink, an inability to limit one's drinking in any given occasion, and anxiety over a long period of drinking'. (p. 658)

Similarly, Haarer (1984) stated:

$[T]$ he likeliest indicator of alcoholism is the person's inability ... to control or to manage how much he/she will consume on a particular drinking occasion [so much so that] drinking becomes compulsive, profoundly affecting thoughts, emotions, spirituality - the whole person'. (p. 44)

The concept of dependence makes the situation of the alcoholic better understood. According to DeJong (1985), that a person is dependent on alcohol implies that the alcoholic drinks to survive. The ex-alcoholic pastor explains:

As soon as the alcoholic is deprived of alcohol-on-demand, his / her survival is at stake. It is without the comfort of the bottle that an alcoholic gets a grim and threatening view of life ... He cannot enjoy life without a sufficient level of alcohol in his bloodstream ... Alcohol is an integral element of what he/she deems the 'good life'. (DeJong 1985:49)

In view of the fact that alcoholism involves physical addiction and the fact that it has effects on the body, some consider alcoholism a disease. As Haarer (1984) explained it:

With physical dependence the alcoholic needs alcohol to feel normal. Without the drug, the alcoholic goes through a difficult withdrawal process. Dependency may involve blackouts - an amnesia for some of the time spent when drunk (i.e., forgetting recent events which occur during drinking). There is also the inability to control drinking and their own will once alcohol is taken into the body. In this view, once a person has allowed his/ her will to be overtaken by alcohol through abuse, that person is sick and can no longer help himself/herself. (p. 47)

More importantly, 'Physicians and medical insurance companies accept alcoholism as a disease because it is predictable, progressive, physiologically debilitating, and treatable' (Collins 2007:658). But some people, especially 'Christians who are influenced by the temperance movement', have rejected considering alcoholism as a disease; rather, for them, alcoholism is a sin, and all that the alcoholic needs is to repent (Haarer 1984:47). However, in anticipation of the role of the church in curbing alcoholism, whilst not denying its personal and moral dimensions, the disease concept

[I]s most useful because it has opened the door for the kinds of attitudes that make it most likely for the alcoholic to receive help [because it] has not carried the moral stigma [of the] temperance approach. (Haarer 1984:48)

In the view of Collins (2007), '[b]y calling alcoholism a disease, [certain] individuals are less likely to be condemned and more likely to get treatment, which insurance companies will finance'(p. 658).

As seen earlier, scholars have classified the effects of alcoholism in Proverbs 23, particularly verse 29, into emotional, physical and social categories. All of these are applicable in Nigeria. In this regard, many have pointed out that alcoholism has diverse 'social, health, economic, [and] psychological' effects on abusers and the society at large (Dumbili 2013:27). Nelson (2015) stated:

$[A]$ lcohol is recognized as a contributory factor in a wide range of social problems, including anti-social behaviour, crime, violence, domestic violence, strained relationships, family breakdown, and child abuse and neglect. (p. 106) 
In proverbs the list follows the order of emotional, social and physical effects, as mentioned earlier, but in the present work the health of the alcoholic is considered the most paramount, which is often both psychological and physical; hence, the health risk factor is discussed first, followed by the effects on the family and the larger society.

In associating alcoholism with woes and sorrow, Proverbs 23:29 give a hint on the psychological effects of alcohol on the abuser; however, in modern times, alcohol has been linked to psychological problems wider than sorrow. Wilson (1989:6) referred to alcohol as 'the most dangerous psychoactive (mind altering) drug'. According to Haarer (1984), alcoholics 'struggle with feelings of low self-esteem, fear, guilt, resentfulness towards authority, lack of power [and] loss of relationships' (p. 46). Collins (2007) listed disorders arising from alcoholism to include 'a wide variety of mental conditions [such as] liver disorders, psychotic disorder, anxiety and dementia' (p. 658). In terms of physical health, today several studies have indicated a high rate of health risks associated with heavy drinking. According to Roerecke et al. (2008), 'The World Health Organization (WHO) Comparative Risk Assessment Study in 2000 showed that alcohol played a significant factor in determining [the] burden of disease in Africa' (p. 1). Other studies have similarly pointed to chronic disease conditions as consequences of harmful consumption of alcohol (Gureje et al. 2007; Obot 2007, both cited in Roerecke et al. 2008:1). For instance, it is proven that:

$[H]$ armful use of alcohol is a risk factor for ... diseases such as cardiovascular disease, cancers ... and chronic liver disease ... It is also known that about $4.5 \%$ of the global burden of disease, measured by disability-adjusted life years (DALYs) is due to alcohol, 25\% of [which] are due to the relationship of alcohol to liver cirrhosis, CVD and cancers. (Chukwuonye et al. 2013:179)

Bates et al. (n.d.) stated that studies have identified alcoholism as one of the causes of 'high blood pressure and ... stroke' (p. 7). In Nigeria, data on the health and social consequences of drinking are still inadequate 'but there is consensus in research findings that alcohol use disorders account for the highest proportion of people admitted for treatment for their substance use problems' (Obot 2007:520). As discussed earlier, Proverbs 23:29 indicate wounds and injuries amongst the effects of drunkenness; the indication which is relevant in modern times in the link between alcohol and the risk factor for disability and premature death. According to Chukwuonye et al. (2013), a world report from the WHO affirms that hazardous or harmful use of alcohol was responsible for about 2.3 millionglobal deaths in 2004, accounting for 3.8\% of all global mortality' (2004:179). In sub-Saharan Africa, alcohol abuse has been identified as 'the leading risk factor for death and disability ... amongst African male adolescents ... [accounting] in 2012 for $6.4 \%$ of all deaths' (Ferreira-Borges, Parry \& Babor 2017:3). In Nigeria, 'road traffic accidents because of drunk-driving [have] continued to claim lives yearly' (Dumbili 2013:28).
As seen in the exegesis, Proverbs 23:29 identify social problems such as constant fighting and complaining as effects of alcohol abuse; today's experience has shown that greater social problems arise from misuse of alcohol. 'It is estimated that an average alcoholic deeply affects at least four other persons [starting with] the family and those with whom the family interacts' (Haarer 1984:59). Haarer further explains that the children of an alcoholic parent are most likely to become alcoholic themselves, to marry alcoholics and are likely to develop mental illness (Haarer 1984:61). Several studies have established a strong link between misuse of alcohol and domestic violence. A study showed that 'alcohol use was involved in 51\% of the cases in which a husband stabbed a wife' (WHO 2004:4). This is accounted for by the fact that intoxication 'triggers male violence against their spouses' (Nelson 2015:109). In a study conducted by Nelson (2015) in Oron, Akwa IbomState, Nigeria, a significant percentage of the 'participants stated that they were more likely to be provoked by their spouses' behaviour when they were drunk than when they were sober' (p. 109). Alcohol abuse has led to a lot of marital instability, divorce and related problems that affect the children of the families concerned (Nelson 2015:110). Uncontrolled drinking has also been identified as a source of societal violence and its attendant problems. In this light, the idea of having wounds without cause in Proverbs 23:29 is also relevant here in the sense that people who drink heavily are usually prone to violence, which often causes 'injuries, impairments and disabilities' for themselves and other members of the society (Nelson 2015:110). In another place, Nelson (2014) opined that the link between alcohol and violent crimes has been established, pointing out that studies have:

[I]mplicated alcohol in one-half to two-thirds of homicides, in one-fourth to nearly one half of cases of serious assaults, and in more than one-fourth of rape cases ... [and] one-half of everyday incidence of violence. (p. 56)

This fact is exemplified in Nigeria, for example, in the higher institutions where cult clashes have been on the increase in which 'youths cruelly maim their rivals with dangerous weapons, [and][t]his has been linked to the fact that alcohol is hazardously used amongst Nigerian youths' (Dumbili 2013:27). Alcohol has also been found to be a fuelling factor in the increasing rate of communal clashes in the country (Dumbili 2013:27).

Unfortunately, in spite of these adverse effects of alcoholism in Nigeria, government has not been able 'to design [adequate] intervention measures for alcohol [production and] consumption' (Odejide 2006:29). Instead, the country has continued to rely on self-regulation championed by alcohol producers, which is reflected mainly in the phrase 'Drink Responsibly' that follows alcohol advertisements in both print and electronic media. This, of course, has been of little consequence in combating alcohol abuse (Dumbili 2013:24; Obot 2007:520). Therefore, there is a wide vacuum for the church to occupy with regard to curbing alcoholism and its effects in Nigeria. Hence, in the following section this 
article examines how the church can exploit Proverb's 23 passage as a textual basis for responding to the menace of alcoholism

\section{The role of the church in Nigeria in curbing alcoholism}

Writing on the attitude of pentecostal churches in Nigeria towards alcohol, Nelson (2014:121) stated, 'A coherent Pentecostal theology of alcohol is almost non-existent'; however, the statement is applicable not only to the Pentecostals but also to most of the denominations, as very few of them have any formal statement of faith concerning attitude to alcohol. "The subject is rarely taken up in regular bible studies or developed as catechism. It may be mentioned occasionally in sermons, but mostly in passing' (Nelson 2014:121). The Roman Catholic Church is amongst the few that have official position on alcohol; as stated in its catechism:

[T] he virtue of temperance disposes us to avoid every kind of excess: the abuse of food, alcohol, tobacco, or medicine. Those incur grave guilt who by drunkenness ... endanger their own and others' safety. (Udodiong 2018:online).

This is also the stand of the Anglicans and the Lutherans on alcohol consumption, whereas the Seventh-day Adventists recommend total abstinence (Udodiong 2018). Like the latter, most of the pentecostal and neo-pentecostal denominations espouse 'a prohibitionist view of alcohol, as part of a rigid insistence on a strict moral ideology' (Nelson 2014:119). Nevertheless, as the preceding section has shown, the preaching against misuse of alcohol has had very little effect in Nigeria; hence, the church has to develop other methods in responding to the problem of alcoholism.

Proverbs 23:29-35 are relevant for this assignment, first in creating the awareness for the church that alcoholics abound not just in the society but right there in the congregations. Bonhoeffer (1971) stated that '[T]he church is the church only when it exists for others [sharing] ... in secular problems of ordinary human life' (cited in Mangayi 2014:135). In this regard:

[A]ddressing the issue of alcohol addiction will assist the congregation in understanding ministry as an outward healing experience for other people who are hurting and need help from the church. (Jones 2013:8)

The church, more than any organisation, is most relevant when it comes to healing for alcoholics. Bates et al. (n.d.) affirmed that studies of 'inverse relationship between religiosity and substance abuse disorders ... have associated spiritual and religious elements with more positive outcomes for substance-abusing clients in treatment' (p. 10). To embark on this duty, the church has to put in place an alcohol recovery programme. The starting point is for the church to make itself accessible to people suffering from the disease of alcoholism. It is pertinent to note that the general public has a negative attitude towards alcoholics. Because the society does not understand alcoholism as a disease, it makes the alcoholic to feel that 'he or she is rejected and alone, and isolated from others' (DeJong 1985:55). Citing passages such as 1 Corinthians 5:11-13, sometimes some members of the church actually believe that 'an alcoholic should be removed from church' (Flower 2017). Hence, the church must begin by teaching its members to have a caring attitude towards alcoholics. Church members must be taught to 'avoid stigmatisation, destructive criticisms and gossips against alcoholics but educate them with passion and love. This is the kind of attitude that [leads to] positive and progressive change' (Njoku 2012:72). As Haarer (1984) put it, people must 'get past negative feelings, gain understanding and develop attitudes of compassion and acceptance towards [alcoholics] without [necessarily] accepting their destructive behaviour' (p. 20). The ex-alcoholic pastor, Alexander DeJong (1985), again writes on how persuasion from people helped him to recover:

Gradually ... I came to see patterns of drinking which were inappropriate. This awareness was fostered by those who resolutely tried to reduce, rather than heighten, my guilt feelings ... Factual accounts of inappropriateness were presented to me without moral condemnation or religious disapproval. Confrontation, not condemnation, helped me enormously. (p. 57)

The church's alcohol recovery programme should be built into its scheme of activities. It will involve reiterating the teaching of Proverbs 23:29-35 and similar texts periodically in sermons, in the activities of the various groups of the church, particularly the men's and youth fellowships; it should be reflected in catechism, bulletins, magazines and all the teaching manuals of the church; it should be built into the curricula of the church's schools and colleges. For effectiveness, the alcohol recovery programme should involve professional counsellors. Flower (2017) stated that the church cannot get involved 'in diagnoses or administering recovery ... [but it] could help to connect [alcoholics] with professional help or recovery groups' (online). The way this can work in Nigeria is for each denomination or local church to constitute an alcohol recovery committee. This committee informs the public of the church's recovery programme for alcoholics through the media and other means; it identifies alcoholics in the congregations and in the society and designs a method to get the programme to serve them. Families who have alcoholic relatives will be very helpful in getting such relatives to respond to the clarion call. This counselling unit will use the Proverb's 23 passage and similar texts as part of the instruments for counselling.

As part of this programme, it will be very helpful for the church in Nigeria to establish Alcoholics Anonymous (a.k.a. Al-Anon or AA) groups, such groups are very popular in Europe and America. According to Bates et al. (n.d.):

AA was founded by Bill Wilson and his physician, Doctor Bob Smith in 1935. [It] is a global, community-based program that was created to help those struggling with problematic drinking get sober with the support of their peers through daily meetings and discussions surrounding addiction. (p. 12) 
The purpose of Alcoholics Anonymous is 'to help alcoholics achieve sobriety' (Simon-Peter 2015:online); it is also to provide 'group interaction for the help of those who live with alcoholics' (DeJong 1985:115). Alcoholics Anonymous is characterised by its regular meetings, which are designed principally 'to preserve the delicate treasure of sobriety' (DeJong 1985:115). However, the AA meetings are not restricted to alcoholics but open to their relatives or other interested persons. It is intended that the fellowship can build in such persons 'confidence and serenity, equipping [them] to deal constructively and decisively with the alcoholic' (DeJong 1985:116). Al-Anon has been well known for its 12 steps $^{2}$ for recovery which have been adapted by other self-help and addiction recovery groups, such as 'Gamblers Anonymous and Narcotics Anonymous' (Bates et al. n.d.:12).

Today, 'AA has an estimated 2 million members worldwide in 115000 groups' (Simon-Peter 2015:online). Mapunda (2016) had suggested that the Catholic Church in Tanzania can adapt the Al-Anon 'program ... into our family healing ministry' in the parishes (online). The various denominations in Nigeria can similarly adapt the tenets of AA to their specific conditions. Along with their other activities, Proverbs 23:29-35 are recommended for reading and exposition regularly in the Al-Anon meetings. It is believed that if conducted conscientiously, the church's alcohol recovery programme will go a long way in getting many alcoholics retain sobriety and thus considerably reduce the social effects of alcoholism in Nigeria.

\section{Conclusion}

This article found the relevance of Proverbs 23:29-35 in Nigeria in the fact that it creates awareness for the church concerning the prevalence of alcohol abuse with its adverse effects on the abusers and the society as a whole. The church can respond to this problem by constituting an alcohol recovery programme in which the proverb's text will be part of the teaching and counselling instruments. This programme begins with the church encouraging its members to have a compassionate attitude towards people suffering from the disease of alcoholism. The programme would involve engaging professional counsellors in extending a healing outreach to alcoholics. It would involve the establishment of groups of Alcoholics Anonymous in which the alcoholics themselves would participate in their own process of regaining and sustaining sobriety. In this way, the church would enable many alcoholics to obtain healing and thus considerably reduce the social effects of alcoholism in Nigeria.

\section{Acknowledgements Competing interests}

The author has declared that no competing interests exist.

2.These are a sort of confession creed, which alcoholics can recite from time to time to sustain sobriety (see Bates et al. n.d.:12)

\section{Author's contributions}

I declare that I am the sole author of this research article.

\section{Ethical consideration}

This article followed all ethical standards for a research without direct contact with human or animal subjects.

\section{Funding information}

This research received no specific grant from any funding agency in the public, commercial or not-for-profit sectors.

\section{Data availability statement}

Data sharing is not applicable to this article as no new data were created or analysed in this study.

\section{Disclaimer}

The views and opinions expressed in this article are those of the author and do not necessarily reflect the official policy or position of any affiliated agency of the author.

\section{References}

Bacchiocchi, S., 2001, Wine in the bible: A biblical study on the use of alcoholic beverages, Biblical Perspectives, Berrien Springs, MI.

Bates, J., Campbell, C., Cann, M., Crosby, A. \& Herrick, K., n.d., 'Alcoholism: Awareness and alleviation of addiction', Academia, viewed 10 October 2019, from https:// www.academia.edu/34656319/Alcoholism_Awareness_and_Alleviation_of_ WwW.academia.edu/34656319/Alcoholisn?email_work_card=view-paper.

Bible Study Tools, 2020, 'John Gill's exposition of the bible/proverbs 23', Bible Study Tools, viewed 08 April 2020, from https://www.biblestudytools.com/ commentaries/gills-exposition-of-the-bible/proverbs-23/.

Birch, B.C., Brueggemann, W., Fretheim, T.E. \& Petersen, D.L., 2005, A theological introduction to the old testament, 2nd edn., Abingdon, Nashville, TN.

Boadt, L., 1984, Reading the Old Testament: An introduction, Paulist, New York, NY.

Bonhoeffer, D., 1971, Letters and papers from prison, enlarged edn., SCM Press, London.

Boone, R., n.d., 'Common assumptions about wine in the bible', Bible Baptist, viewed 01 September 2019, from http://www.biblebaptist-sm.com/home/180009341/ $180009341 /$ files/Common $\% 20$ Assumptions $\% 20$ about $\% 20$ Wine $\% 20$ in $\% 20$ the $\% 20$ Bible.pdf.

Bryceson, D.F., 2002, 'Alcohol in Africa: Substance, stimulus and society', Academia, viewed 27 August 2019, from https://www.academia.edu/9887054/Alcohol_in Africa_Substance_Stimulus_and_Society?auto=download.

Charles, H.H., 1966, Alcohol and the bible, Herald Press, Scottdale, PA.

Chukwuonye, I.I., Chuku, A., Onyeonoro, U.U., Madukwe, O.O., Oviasu, E. \& Ogah, O.S., 2013, 'A rural and urban cross-sectional study on alcohol consumption among adult Nigerians in Abia State', International Journal of Medicine and Biomedical Research 2(3), 179-185. https://doi.org/10.14194/ijmbr.234

Collins, G.R., 2007, Christian counseling: A comprehensive guide, 3rd edn., Thomas Nelson, Nashville, TN.

DeJong, A.C., 1985, Help and hope for the alcoholic, 3rd edn., Tyndale House, Wheaton, IL.

Dumbili, E., 2013, 'Changing patterns of alcohol consumption in Nigeria: An exploration of responsible factors and consequences', Medical Sociology Online 7(1), 20-33, viewed 28 August 2019, from www.medsoconline.org.

Dumbili, E.W. \& Williams, C., 2016, 'Anywhere, everywhere: Alcohol industry promotion strategies in Nigeria and their influence on young people', African Journal of Drug \& Alcohol Studies 15(2), 136-152.

Ferreira-Borges, C., Parry, D.H. \& Babor, T.F., 2017, 'Harmful use of alcohol: A shadow over sub-Saharan Africa in need of workable solutions', International Journal of Environmental Research and Public Health 14(346), 1-12. https://doi.org/10. 3390/ijerph14040346

Flower, D., 2017, 'Christianity, alcoholics, and addictions: How should the church deal with addictions and addicts?', Wordpress.com, viewed 08 October 2019, from https://missdaisyflower.wordpress.com $/ 2017 / 07 / 07 / \%$ E2\%80\%A2-christianityalcoholics-and-addictions-how-should-the-church-deal-with-addictions-andaddicts/.

Garrett, D.A., 1993, The new American commentary, 14 vols, Broadman, Nashville, TN. 
Goldingay, J.E., 1994, 'Proverbs', in D.A. Carson, G.J. Wenham, J.A. Motyer \& R.T. France (eds.), New bible commentary, pp. 584-608, Inter Varsity Press, Nottingham.

Gureje, O., Degenhardt, L., Olley, B., Uwakwe, R., Udofia, O., Wakil, A. et al., 2007, 'A descriptive epidemiology of substance use and substance use disorders in Nigeria during the early 21 st century', Drug and Alcohol Dependence 91(1), 1-9. https:// doi.org/10.1016/j.drugalcdep.2007.04.010

Haarer, L.D., 1984, The church's attitudes toward alcohol, Faith and Life Press, Newton, KS and Mennonite Publishing House, Scottdale, PA.

Helicopter View, 2017, 'Top-10 alcohol-drinking countries in Africa', Helicopter View viewed 27 August 2019, from http://helicopter-view.com/blog/top-10-alcoholdrinking-countries-in-africa1.

Henry, M., 2012, 'Drunkenness - Matthew Henry commentary Proverbs 23:29-35', Verloreseun, viewed 02 September 2019, from https://verloreseun.wordpress. com/2012/03/30/drunkenness-matthew-henry-commentaryproverbs-2329-35/.

Jones, S.D., 2013, 'The church and alcoholism: A model for empowering rivertown united methodist church to address the addiction of alcohol', Doctoral dissertation, The Atlanta Theological Association.

Kerr, E.A., 1968, Alcohol and the scriptures, 2nd edn., Presbyterian Church of Victoria, Victoria.

Lasebikan, V.O. \& Ayinde, O., 2012 'Rapid situation assessments of alcohol and substance use among commercial vehicle drivers in Nigeria', East African Medical Journal 89(11), 363-371.

Lasebikan, V.O., Ayinde, O., Odunleye, M., Adeyefa, B., Adepoju, S. \& Fakunle, S., 2018 'Prevalence of alcohol consumption and alcohol use disorders among outdoor drinkers in public open places in Nigeria', BMC Public Health 18(400), 1-10. drinkers in public open places in Nigeria',
https://doi.org/10.1186/s12889-018-5344-6

Mangayi, L.C., 2014, 'Mobilising the local church for social justice and reconciliation: Theological /missiological reflections on the ministries of the Baptist Union of Southern Africa (1996-2011)', The South African Baptist Journal of Theology 132-149.

Mapunda, B.R., 2016, 'The Catholic Church and alcoholism', in Missionaries of Africa White Fathers, viewed 10 October 2019, from https://mafrome.org/the-catholicchurch-and-alcoholism/.

Nelson, E.E., 2014, “"To drink or not to drink?": Moral ambiguity of alcohol in the Pentecostalist imagination', African Journal of Drug and Alcohol Studies 13(2), $118-129$.
Nelson, E.E., 2015, 'Alcohol use, intimate partner violence and family well-being: A qualitative study in Oron, Nigeria', African Journal of Drug and Alcohol Studies 14(2), 105-113.

Njoku, E.U., 2012, 'A study of Proverbs 23:29-35 and the effects of alcoholism in Nigerian society: The role of the church', M.A. thesis, UNN, Unsukka.

Nugent, P., 2017, 'Alcohol in Africa', African Studies Centre, viewed 27 August 2019, from https://www.ascleiden.nl/content/webdossiers/alcohol-africa.

Obot, I., 2007, 'Nigeria: Alcohol and society', Online Library 102(4), 519-522. https:// doi.org/10.1111/j.1360-0443.2006.01619.x.

Odejide, O.A., 2006, 'Alcohol policies in Africa', African Journal of Drug and Alcohol Studies 5(1), 28-39.

Patton, W., n.d., 'Bible wines or the laws of fermentation and the wines of the ancients', Int'l College of the Bible, viewed 01 September 2019, from http://icotb. org/resources/Patton,William-BibleWines.pdf.

Roerecke, M., Obot, I.S., Patra1, J. \& Rehm, J., 2008, 'Volume of alcohol consumption, patterns of drinking, and burden of disease in sub-Saharan Africa', African Journa of Drug and Alcohol Studies 7(1), 1-15. https://doi.org/10.4314/ajdas.v7i1.46355

Ross, A.P. 1994 'Proverbs', in K.L. Barker \& J.R. Kohlenberger (eds.), The expositor's bible commentary, pp. 938-1008, Zondervan, Grand Rapids, MI.

Rylaarsdam, J.C., 1982, 'Hebrew wisdom', in M. Black \& H.H. Rowley (eds.), Peake's commentary on the bible, pp. 386-390, Van Nostrand, Wokingham.

Simon-Peter, R., 2015, '15 things alcoholics anonymous can teach the church', Ministry Matters, viewed 12 October 2019, from https://www.ministrymatters.com/all/ entry/6101/15-things-alcoholics-anonymous-can-teach-the-church.

Studylight.org, 2001-2020, 'Proverbs 23', Studylight.org, viewed 08 April 2020, from https://www.studylight.org/commentaries/tpc/proverbs-23.html.

Udodiong, I., 2018, 'Is it a sin for pastors and Christians to drink?', Pulse Nigeria viewed 27 August 2019, from https://www.pulse.ng/communities/religion/ alcohol-is-it-a-sin-for-pastors-and-christians-to-drink/xqwteg0.

Ulrich, T.R., 2018, 'In pursuit of organizational wisdom: An exegesis of Proverbs 22:17 - 24:22', Emerging Leadership Journeys 11(1), 100-125.

Wilson, S.D., 1989, Counseling adult children of alcoholics, Word publishing, London.

World Health Organisation (WHO), 2004, Global status report: Alcohol policy, WHO, Geneva.

Zuck, R.B., 1991, 'A theology of the wisdom books and the Song of Songs', in R.B. Zuck (ed.), A biblical theology of the Old Testament, pp. 207-255, Moody Press, Chicago, IL. 